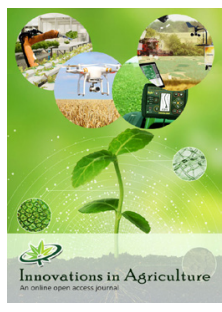

ISSN: $2617-1295$

Received: Janauary 26, 2020

Accepted: April 22, 2020

Published: April 04, 2020

*Corresponding Author:

Maysoun Mohamad Saleh

E-mail:mzainsamasaleh@

gmail.com

\section{Evaluation of yield traits in some primitive wheat genotypes to ensure sustainability of wheat production}

\author{
Maysoun Mohamad Saleh"*, Fariza. Alsarhan Alsarhan² \\ ${ }^{1}$ General Commission for Scientific Agricultural Research (GCSAR), Genetic Resources Department, Damascus, \\ Syria, ${ }^{2}$ General Commission for Scientific Agricultural Research (GCSAR), Al-Raqqa Research Center, Al-Raqqa, Syria
}

\begin{abstract}
Study was conducted at Al-Raqqa Research Centre in The General Commission for Scientific Agricultural Research in Syria during the growing season 2011/2012. Eight primitive wheat genotypes and two local cultivated varieties were planted in Randomized Complete Block Design in three replications, yield components (number of fertile tillers, number and weight of grains per spike and weight of thousand grain) were studied. Results showed that the genotype Persian 64 was significantly superior in three traits of yield components (number of fertile tillers, number and weight of grains per spike) comparing to the check sham5, and also the genotype Polish 194 was significantly superior in weight of thousand grain comparing to both checks sham 3 and sham $5(53.12,40.80,40.02)$ g respectively with an increase rate $30.20 \%$ and $32.73 \%$ comparing to both checks sham 3 and sham 5 respectively. It is recommended to use the superior genotypes in breeding programs to ensure the sustainability of wheat production.
\end{abstract}

KEYWORDS: Genotypes, Primitive Wheat, Yield Traits, Correlation

\section{INTRODUCTION}

Wheat is a main cultivated crop in many countries in the world [1], used as food and fodder [2], and consider as the main crop in Mediterranean region [3]. In order to improve economy in general Breeders are still working to develop wheat yield [4] by using different genotypes of wheat [5] and exploit the genetic variation within it [6], and to improve selection [7] depending on yield traits [8].

Emmer wheat Triticum dicoccum is valuable for the high content of protein and glutin [9]. Each of Triticum dicoccum, Triticum polonicum, Triticum persicum are characterized as important primitive genotypes to develop wheat production.

Fertile tiller number and grain number per spike and thousand grain weight are very important traits to develop final production of wheat $[10,11,12]$. Correlation analysis is an effective tool in breeding programs [13] to increase yield [14] via yield traits [15].

Dogen [16] found that grain number per spike was positively correlated with grain weight per spike and thousand grain weight, and Mahmood et al. [17] also found positive correlation between grain number per spike and thousand grain weight.
Objectives of this study were to define variation between wheat genotypes regarding yield traits in order to develop seed production, and to be provide wheat breeders with the best significant genotypes, and to study the correlation between studied traits.

\section{METHODS AND MATERIALS}

Eight primitive tetraploid wheat genotypes and two local cultivated varieties were planted in Randomized Complete Block Design in three replications at Al-Raqqa research center in the general commission for scientific agricultural research in Syria during the growing season 2011/2012, each plot contained six rows, row length was one meter, with distance of $25 \mathrm{~cm}$ between rows and $5 \mathrm{~cm}$ between plants in the same row, and the depth of planting was $3-5 \mathrm{~cm}$.)

Yield components were studied from ten selected plants:

- Fertile tillers number per plant: Number of fertile tillers of each genotype were counted at maturity in each replication and average was computed.

- Grain number per spike: The main spike was threshed manually and numbers of grains per spike were counted for each genotype.

- Grain weight per spike: Grain per spike was weighed using electric balance for each genotype in each replication.

Copyright: $\odot$ The authors. This article is open access and licensed under the terms of the Creative Commons Attribution License (http://creativecommons.org/licenses/by/4.0/) which permits unrestricted, use, distribution and reproduction in any medium, or format for any purpose, even commercially provided the work is properly cited. Attribution - You must give appropriate credit, provide a link to the license, and indicate if changes were made. 
- Thousand grain weight: 500 grains were counted randomly from each genotype and weighed on electric balance then adjusted to 1000 grain weight.

Results were analyzed by Genstat.12 program according to Duncan's multiple range test, and correlation was analyzed by SPSS.12 program.

\section{RESULTS}

\section{Fertile Tillers Number/Plant}

Significant variations were found between studied genotypes in Fertile tillers number, which ranged from 13.33 in Polish 194 to 26.33 in Emmer124, with a grand mean of 22.12 fertile tiller. Results showed that (Emmer124, Emmer94, Polish193, Persian64, Persian49) were all significantly superior in fertile tiller number $(26.33,26.00,23.67,23.67,23.33)$ respectively with an increase rate $(42.23,40.54,27.95,27.95,26.11) \%$ comparing to the check sham 5 (18.50) (Table 1). These results are in agreement with many researchers [18-21].

\section{Grain Number/Spike}

Significant variations were found between studied genotypes in Grain number/spike, it ranged from the lowest number 41.33 in

Table 1: Fertile Tillers in genotypes

\begin{tabular}{lccc}
\hline Geno & Fertile Tillers & \multicolumn{2}{c}{ Difference Rate\% comparing to checks } \\
\cline { 3 - 4 } & & Sham3 & Sham5 \\
\hline Emmer67 & $18.67 \mathrm{~b}$ & $-26.29 *$ & 0.92 \\
Emmer94 & $26.00 \mathrm{a}$ & 2.65 & $40.54^{*}$ \\
Emmer124 & $26.33 \mathrm{a}$ & 3.95 & $42.32^{*}$ \\
Polish193 & $23.67 \mathrm{a}$ & -6.55 & $27.95^{*}$ \\
Polish194 & $13.33 \mathrm{c}$ & $-47.37^{*}$ & $-27.95^{*}$ \\
Persian49 & $23.33 \mathrm{a}$ & -7.90 & $26.11^{*}$ \\
Persian57 & $22.33 \mathrm{ab}$ & -11.84 & 20.70 \\
Persian64 & $23.67 \mathrm{a}$ & -6.55 & $27.95^{*}$ \\
Sham3 & $25.33 \mathrm{a}$ & & \\
Sham5 & $18.50 \mathrm{~b}$ & & \\
Mean & 22.12 & & \\
CV\% & 11.4 & & \\
\hline
\end{tabular}

* refers to significant difference

Table 2: Grain number/spike in genotypes

\begin{tabular}{lccc}
\hline Geno & Grain number/spike & Difference Rate\% comparing to checks \\
\cline { 3 - 4 } & & Sham3 & Sham5 \\
\hline Emmer67 & $45.00 \mathrm{def}$ & $-29.69^{*}$ & $-26.83^{*}$ \\
Emmer94 & $47.00 \mathrm{~d}$ & $-26.56^{*}$ & $-23.58^{*}$ \\
Emmer124 & $43.33 \mathrm{def}$ & $-32.30^{*}$ & $-29.54^{*}$ \\
Polish193 & $56.33 \mathrm{~d}$ & $-11.98^{*}$ & $-8.41^{*}$ \\
Polish194 & $46.00 \mathrm{def}$ & $-28.13^{*}$ & $-25.20^{*}$ \\
Persian49 & $41.33 \mathrm{def}$ & $-35.42^{*}$ & $-32.80^{*}$ \\
Persian57 & $47.00 \mathrm{~d}$ & $-26.56^{*}$ & $-23.58^{*}$ \\
Persian64 & $81.33 \mathrm{a}$ & $27.08^{*}$ & $32.24^{*}$ \\
Sham3 & $64.00 \mathrm{~b}$ & & \\
Sham5 & $61.50 \mathrm{~b}$ & & \\
Mean & 53.28 & & \\
CV\% & 5.6 & & \\
\hline
\end{tabular}

* refers to significant difference
Persian 49 to the highest number 81.33 Persian 64, with a grand mean of 53.28 grain. Persian 64 was significantly superior in grain number per spike (81.33) comparing to both checks sham 3 and sham $5(64.00,61.50)$ respectively with an increase rate $(27.08$, $32.24) \%$ respectively (Table 2 ). These results agree with the findings of Saleh [22] and others [23,24,25,26].

\section{Grain Weight/Spike}

Significant variations were found between studied genotypes in Grain Weight/Spike, grand mean was $1.873 \mathrm{~g}$, the range was from 1.267 equally in both genotypes (Polish193, Persian49) to 2.800 in Polish 194. Results refereed that both of Polish194 and persian64 were significantly superior in grain weight per spike $(2.800,2.733)$ g respectively with an increase rate $(21.74,18.83)$ $\%$ respectively comparing to check sham 5 (2.300) g (Table 3 ). These results are in agreement with many researcher $[27,28]$.

\section{Thousand Grain Weight g}

Significant variations were found between studied genotypes in thousand Grain Weight, which ranged from $23.76 \mathrm{~g}$ in Polish193 to $53.12 \mathrm{~g}$ in Polish 194, with a grand mean of $34.9 \mathrm{~g}$. Results indicated that Polish194 was significantly superior in thousand grain weigh (53.12) g with an increase rate $(30.20,32.7) \%$ comparing to both checks sham 3 and sham $5(40.80,40.02)$ respectively (Table 4). These results are in agreement with many researcher [24,29-31].

Table 3: Grain weight/spike g in genotypes

\begin{tabular}{lccc}
\hline Geno & Grain weight/spike & \multicolumn{2}{c}{ Difference Rate\% comparing to checks } \\
\cline { 3 - 4 } & & Sham3 & Sham5 \\
\hline Emmer67 & $1.300 \mathrm{c}$ & $-47.30^{*}$ & $-43.48^{*}$ \\
Emmer94 & $1.433 \mathrm{C}$ & $-41.91^{*}$ & $-37.70^{*}$ \\
Emmer124 & $1.500 \mathrm{c}$ & $-39.20^{*}$ & $-34.78^{*}$ \\
Polish193 & $1.267 \mathrm{c}$ & $-48.64^{*}$ & $-44.91^{*}$ \\
Polish194 & $2.800 \mathrm{a}$ & 13.50 & $21.74^{*}$ \\
Persian49 & $1.267 \mathrm{c}$ & $-48.64^{*}$ & $-44.91^{*}$ \\
Persian57 & $1.300 \mathrm{C}$ & $-47.30^{*}$ & $-43.48^{*}$ \\
Persian64 & $2.733 \mathrm{a}$ & 10.78 & $18.83^{*}$ \\
Sham3 & $2.467 \mathrm{ab}$ & & \\
Sham5 & $2.300 \mathrm{~b}$ & & \\
Mean & 1.837 & & \\
CV\% & 12.2 & & \\
\hline
\end{tabular}

* refers to significant difference.

Table 4: Thousand Grain Weight $g$ in Genotypes

\begin{tabular}{lccc}
\hline Geno & Thousand Grain & \multicolumn{2}{c}{ Difference Rate\% comparing to checks } \\
\cline { 3 - 4 } & Weight & Sham3 & Sham5 \\
\hline Emmer67 & 33.12 bcd & -18.82 & -17.24 \\
Emmer94 & $26.66 \mathrm{~cd}$ & $-34.66^{*}$ & -33.38 \\
Emmer124 & $33.65 \mathrm{bcd}$ & -17.52 & -15.92 \\
Polish193 & $23.76 \mathrm{~d}$ & $-41.76^{*}$ & $-40.63^{*}$ \\
Polish194 & $53.12 \mathrm{a}$ & $30.20^{*}$ & $32.73 *$ \\
Persian49 & $26.86 \mathrm{~cd}$ & $-34.17^{*}$ & -32.88 \\
Persian57 & $37.00 \mathrm{bcd}$ & -9.31 & -7.55 \\
Persian64 & $33.65 \mathrm{bcd}$ & -17.52 & -15.92 \\
Sham3 & 40.80 & $\mathrm{~b}$ & \\
Sham5 & $40.02 \mathrm{bc}$ & & \\
Mean & 34.9 & & \\
CV\% & 19.9 & & \\
* & &
\end{tabular}


Table 5: Correlation between Studied Traits

\begin{tabular}{|c|c|c|c|c|}
\hline & $\begin{array}{l}\text { Fertile } \\
\text { Tiller }\end{array}$ & $\begin{array}{l}\text { Grain Number/ } \\
\text { Spike }\end{array}$ & $\begin{array}{l}\text { Grain Weight/ } \\
\text { Spike }\end{array}$ & $\begin{array}{c}\text { Thousand } \\
\text { Grain } \\
\text { Weight }\end{array}$ \\
\hline Fertile Tiller & 1 & & & \\
\hline $\begin{array}{l}\text { Grain number/ } \\
\text { Spike }\end{array}$ & 0.146 & 1 & & \\
\hline $\begin{array}{l}\text { Grain weight/ } \\
\text { Spike }\end{array}$ & -0.284 & $0.620 * *$ & 1 & \\
\hline $\begin{array}{l}\text { Thousand Grain } \\
\text { Weight }\end{array}$ & $-0.494 * *$ & 0.075 & $0.659 * *$ & 1 \\
\hline
\end{tabular}

\section{Correlation}

Results of correlation between studied traits showed a negative significant correlation between fertile tiller number and thousand grain weight $\left(-0.494^{* * *}\right)$, while the correlation between number and weight of grains per spike was positively significant $\left(0.620^{* * *}\right)$ and also positive and significant between thousand grain weight and weight of grains per spike $\left(0.659^{* * *}\right)$ (Table 5.) These findings are in agreement with the findings of many scientists $[9,16,22,32]$.

\section{CONCLUSION AND RECOMMENDATION}

It was concluded that significant valuable variances were found between wheat genotypes in all studied trait. Emmer 124, Emmer 94, Polish 193, Persian 64, Persian 49 were all significantly superior in fertile tiller number, and Persian64 was significantly superior in both grain number and grain weight per spike, and Polish194 was significantly superior in both grain weight per spike and thousand grain weight. Correlation was positive and significant between number and weight of grain per spike as well as between grain weight per spike and thousand grain weight, while correlation was negatively significant between thousand grain weight and fertile number per spike.

\section{RECOMMENDATION}

It is highly recommended to use the superior genotypes in breeding programs to ensure the sustainability of wheat production and to keep evaluating wheat diversity.

\section{REFERENCES}

1. Debasis, P. and P. Khurana. (2001). Wheat biotechnology: A mini review. Electronic J. Biotechnol. ISSN: 0717-3458.

2. Hogg, A.C., T. Sripo, B. Beecher, J.M. Martin and M.J. Giroux. (2004). wheat puroindolines interact to form friabilin and control wheat grain hardness. Theor. Appl. Genet. 108: 1089-1097.

3. Elias, E.M., F.A. Manthey. (2005). end products. In: Royo, C., M.N. Nachit, N. Di fonzo, J.L. Araus, W.H. Pfeiffer and G.A. Slafer (eds.) Durum wheat breeding. Current approaches and future strategies. New York: Food Academic Press, The Haworth Press, 63-86.

4. Ata A., Yousaf B., Khan A S., Subhani G M., Asadullah H. M., Yousaf A. (2014). Correlation and path coefficient analysis for important plant attributes of spring wheat under normal and drought stress conditions. Journal of Biology, Agriculture and Healthcare Vol.4, No.8.

5. Franco, J., J. Crossa, M.L. Warburton, and S. Taba. (2006). sampling strategies for conserving maize diversity when forming core subsets using genetic markers. Crop Science 46:854-864.

6. Rahman, M.M., M.K. Bashar and M.G. Rasul, (2012). Molecular characterization and genetic variation in rice. lap lambert academic publishing GmbH and Co. KG, Saarbrucken, Germany, pp: 1-45.

7. Rahman, M.M., M.G. Rasul, M.K. Bashar, M.A. Syed and M.R. Islam, (2011). Parent selection for transplanted Aman rice breeding by morphological, physiological and molecular diversity analysis. Libyan Agriculture Research Center Journal International, 2(1): 29-35.

8. Tuncturk M., V. Ciftci, (2007). relationships between yield and some yield components in rapeseed (Brassica napus ssp. oleifera L.) cultivars by using correlation and path analysis. Pak. J. Bot., 39(1): 81-84.

9. Bilgi S. A. (2006). Physiological investigations in dicoccum wheat genotypes, master thesis, Department of Crop Physiology College of Agriculture, Dharwad University of Agricultural Sciences, Dharwad.

10. Farooq, J. I. Khaliq, M. Kashif, Q. Ali and S. Mahpara. (2011). genetic analysis for relative cell injury percentage and some yield contributing traits in wheat under normal and heat Stress conditions. Chilean J. Agric. Res. 71(4): 511-520.

11. Munir M., Chowdhry M.A., Malik T. A. (2007). Correlation studies among yield and its components in bread wheat under drought conditions. Int. J. Agri.Biol. 9(2): 287-290.

12. Ali Y., Atta B. M., Akhter J., Monneveux P., Lateef Z. (2008). genetic variability, association and diversity studies in wheat (Triticum aestivum L.) germplasm. Pak. J. Bot. 40(5): 2087-2097.

13. Afroz, R., M.S.H. Sharif and L. Rahman. (2004). Genetic variability, correlation and path analysis in mustard amd rape (Brassica spp.). Bangladesh J. PI. Breed. Genet. 17(1): 59-63.

14. Mahbub M. M., Rahman M. M., Hossain M. S., Mohamad F., Mir Kabir M.M. (2015). Genetic variability, correlation and path analysis for yield and yield components in soybean, American-Eurasian $\mathrm{J}$. Agric. \& Environ. Sci., 15 (2): 231-236, 2015.

15. Tariq M, Ali Q, Khan A, Khan GA, Rashid B, Rahi MS, Ali, A, Nasir IA, Husnain T. (2014) yield potential study of Capsicum annuum L. under the application of PGPR. Adv. life sci.,1(4): 202-207.

16. Dogan R. (2009). the correlation and path coefficient analysis for yield and some yield components of durum wheat (triticum turgidum var. durum I.) in West Anatolia Conditions. Pak. J. Bot., 41(3): 1081-1089.

17. Mahmood, Q., W.D. Lei, A.S. Qureshi, M.R. Khan, Y. Hayat, G. Jilani, I. H. Shamsi, M.A. Tajammal and M.D. Khan. (2006). Heterosis, correlation and path coefficient analysis of morphological and biochemical characters in wheat (Triticum aestivum L. Emp. Thell). Agri. J. 1(3):180-185.

18. Garcia Del Moral L. F., Rharrabti Y., Villegas D., Royo C. (2003) evaluation of Grain Yield and Its Components In Durum Wheat Under Mediterranean Conditions: An Ontogenic Approach, Agronomy Journal, V. 95:266-274.

19. Vollmann J., H. Grausgruber., and P. Ruckenbauer. (2004). genetic variation for plant breeding, proceedings of the $17^{\text {th }}$ EUCARPIA General Congress, 8-11 September, Tullen Austria, Eucarpia and BOKU, University of Natural Resources and Applied Life Sciences, Vienna, Austria.

20. ACPFG. (2005). Taking the stress out of agriculture, Australian center for plant functional genomics PTYLTD, South Australia, Australia.

21. Rabbani G. (2009). inheritance mechanisms of drought tolerance and yield attributes in wheat under irrigated and rainfed conditions, Ph.D thesis, Faculty of Crop and Food Science Pir Mehr Ali Shah, Arid Agriculture University, Rawalpindi, Pakistan.

22. Saleh S. H. (2010). performance, correlation and path coefficient analysis for grain yield and its related traits in diallel crosses of bread wheat under normal irrigation and drought conditions, World Journal of Agriculture Sciences 7(3): 270-279.

23. Kiliç, H., Yağbasanlar T. (2010). The effect of drought stress on grain yield, yield components and some quality traits of durum wheat (Triticum turgidum ssp. durum) cultivars, Not. Bot. Hort. Agrobot. Cluj 38 (1), 164-170.

24. Jahfari H. A. (2004). modeling the growth, radiation use efficiency and yield of new wheat cultivars under varying nitrogen rates. M.Sc. Thesis, Dept. Agro. Univ. Agri., Faisalabad.

25. Sameena S., S. Iqbal., S. Sheikh., and I. Singh. (2000). combining ability analysis over environments in bread wheat in diallel cross data. Agricultural Science Diges, 20(2): 137-138.

26. Saffer-Ul-Hassan M., M. Munir. M. Y Mujahid., N. S. Kisana. A. Zahid. and N. A. Wajid. (2004). genetic analysis of some biometric characters in bread wheat (Triticum aestivum I.). J. Biological Sci., 4: 480-485.

27. Ramiz, T. A., A. Mehraja, and C. M. Alamdar. (2007). genetic 
identification of diploid and tetraploid wheat species with RAPD markers. Turk J Biol, 31:173-180.

28. Khan M. Q., Anwar S., Khan M. I. (2002). Genetic variability for seedling traits in wheat (Triticum aestivum L.) under moisture stress conditions. Asian J. Plant Sci, 1: 588-590.

29. Bhutta W. M. (2006). role of some agronomic traits for yield production in wheat (Triticum aestivum L.) genotypes under drought conditions. Revista UDO Agricola, 6: 11-19.

30. Zanetti, S., M. Winzeler, C. Feuillet, B. Keller, and M. Messmer, (2001).
Genetic analysis of bread-making quality in wheat and spelt. Plant Breed. 120:13-19.

31. Anjum F. M., N. Ahmad, M.S. Butt, and I. Ahmad. (2002). phytate and mineral contents in different milling fractions of some Pakistani spring wheat. Int. J. Food Sci. and Tech.37: 13-17.

32. Thanna, H. A., A. El-Kareem and Amal E. A. El-Saidy. (2011). evaluation of wheat and grain quality of some bread wheat genotypes under normal irrigation and drought stress conditions in calcareous soils. Journal of Biology Sciences, 11 (2): 156-164. 